УдК 343.01

\author{
Ю. В. Філей
}

\title{
СПІВВІДНОШЕННЯ ГУМАНІЗМУ ТА ЕФЕКТИВНОСТІ ЗАХОДІВ КРИМІНАЛЬНО-ПРАВОВОГО РЕАГУВАННЯ
}

Постановка проблеми. Ефективність заходів кримінально-правового реагування визначається рівнем досягнення поставлених перед ними цілей, враховуючи при цьому прийнятність засобів досягнення.

Не можна відривати мету, яку ми прагнемо досягти шляхом застосування заходів кримінально-правового реагування, від засобів, які ми для цього застосовуємо. Із суспільної точки зору неможливо під час оцінювання моральних цінностей розглядати засоби і мету як взаємно виключаючи один одну. Методи, що несумісні з людським достоїнством, ніколи не можуть використовуватися тими, хто перебуває на службі людського прогресу.

Мета закону не в тому, щоб покарати заради кари, а в тому, щоб за допомогою застосування заходів кримінально-правового реагування припинити злочинну діяльність і запобігти вчиненню нових злочинів.

Злочин - це зло для суспільства, покарання це зло для злочинця. Постає питання чи завжди необхідно застосовувати зло до злочинця i якщо необхідно, то якою мірою.

Аналіз останніх досліджень і публікацій. Певні аспекти інститутів кримінальної відповідальності та покарання розглядались у наукових працях вітчизняних та зарубіжних учених, зокрема Г.З. Анашкіна, В.В. Антипова, Л.В. Багрій-Шахматова, М.І. Бажанова, Ю.В. Бауліна, М.О. Бєляєва, І.Г. Богатирьова, Я.М. Брайніна, І.М. Гальперіна, В.В. Голіни, В.К. Грищука, Т.А. Денисової, М.Д. Дурманова, В.К. Дуюнова, О.І. Зубкова, I.I. Карпеця, М.I. Ковальова, О.М. Костенка, В.А. Ломаки, М.I. Мельника, Ю.Б. Мельникової, В.С. Мінської, О.С. Міхліна, А.А. Музики, І.С. Ноя, В.I. Осадчого, А.А. Піонтковського, С.В. Полубинської, О.Л. Ременсона, В.В. Скибицького, В.В. Сташиса, Є.Л. Стрєльцова, В.П. Тихого, Ю.М. Ткачевського, В.М. Трубникова, В.О. Тулякова, Г.А. Туманова, В.І. Тютюгіна, Є.В. Фесенка, І.Я. Фойницького, П.Л. Фріса, В.М. Хомича, М.Д. Шаргородського, С.С. Яценка та інших.

Учені розглядали, як правило, загальні питання застосування заходів кримінально-правового реагування. Водночас досліджень, присвячених 
безпосередньо співвідношенню гуманізму та ефективності заходів кримінально-правового реагування, не $є$ багато.

Постановка завдання. Як показує вивчення історичного досвіду, питання про ступінь суворості покарання завжди стояло перед державою. Тривалий час однією з головних цілей покарання було залякування, а основним видом покарання - страта, котра найчастіше виконувалася привселюдно. Уважалося, що стратою чи відрубування рук злодіям ефективно запобігається крадіжка. Однак історія кримінального права довела неспроможність цих заходів у протидії злочинності. Жорстокості було більше ніж досить, але злочинності вона не викорінила. Тому важливо визначити співвідношення гуманізму та ефективності заходів кримінально-правового реагування.

Виклад основного матеріалу дослідження. Під час застосування заходів кримінально-правового реагування слід виходити не тільки 3 того, яких результатів за допомогою досягає держава в протидії злочинності, але й враховувати, наскільки вони відповідають гуманістичним поглядам суспільства на певному етапі.

О.А. Биков зазначав, що діяння, щодо яких наші предки 100-200 років тому не вважали за можливе обмежитися простою стратою, а вимагали страти кваліфікованої, тепер карається лише каторгою, що пояснюється загальним пом'якшенням норовів, яке $є$ наслідком підвищення рівня морального розвитку суспільства [1, с. 68]. У XVIII ст. під впливом філософії Просвітництва позбавлення волі розглядалось як альтернатива смертної кари, але вже в XIX ст. ефективність позбавлення волі ставиться під сумнів через нездатність виправити засуджених [2, с. 2].

Термін «гуманізм» (від лат. humanus «людський, людяний») - багатоплановий. Гуманізм - це визнання цінності людини як особистості, іï прав на вільний розвиток і прояв своїх здібностей, ствердження блага людини як критерію оцінки суспільних відносин. Принцип гуманізму обмежує судовий огляд вимогою захисту безпеки особистості, а під час визначення покарання особі, яка вчинила злочин, і вимогою економного використання каральних заходів [3, с. 33].

Н. Харуо вважає, що кримінальне законодавство - «необхідне зло», яке має існувати, але необхідно пом'якшити прояви цього «зла». Кримінальне покарання вимагає суворого порівняльного зрівноважування вигоди і шкоди $[4$, с. 75$]$.

Н. Крісті займає ще більш радикальну позицію. Учений уважає, що призначення покарання означає заподіяння болю і призначено саме для цього, тому дослідник пропонує шукати альтернативу покаранню, а не альтернативні покарання [5, с. 19, 22].

Тому доцільно в чинному Кримінальному кодексі знизити розмір позбавлення волі в деяких санкціях. Цю позицію займає й А.П. Козлов, який стверджує, що покарання - це соціальні ліки в боротьбі зі злочинністю. I якщо це так, то наявне співвідношення розміру і виду покарання суперечить людській логіці. Адже чим сильніше ліки, тим менше має бути їх доза, 
тим рідше треба застосовувати, а законодавець діє навпаки, тому «ліки» виявляються недійовими. Далі вчений слушно зазначає, що необхідно змінити законодавчу відповідність виду й розміру покарання: чим тяжчий вид покарання, тим нижче його розміри, тим рідше він має визначатись у санкціях; чим м'якше, тим вище співвідносні розміри покарання, тим частіше застосування в санкціях. Адже в більш суворих видах покарання вже закладений більш значимий карально-виправний ефект [6, с. 71].

Ефективність покарання визначається рівнем досягнення поставлених перед ним цілей. Запобігання злочинам визнане одним із головних напрямів у протидії злочинності. Основна увага приділяється усуненню причин, які породжують злочинність і сприяють вчиненню злочинів. Слід погодитись із твердженням I.M. Даньшина, що суспільство значно більше зацікавлено в тому, щоб не допустити злочин, ніж покарати особу вже після того, як вона завдала шкоду суспільним відносинам [7, с. 97]. У кримінальному праві на зміну періодам приватної помсти та композиції прийшов період запобігання злочинам.

Від того, які цілі ставляться перед покаранням, який сенс вкладається в їх зміст, залежить і характер кримінальної політики в цілому. Ч. Беккарія зазначав, що мета покарання полягає в запобіганні нових діянь злочинця й в утриманні інших від таких дій [8, с. 106]. Ефективність покарання (як головного й основного інструмента кримінально-правового регулювання) визначає й ефективність самого кримінального права як соціального інституту. Ефективність кримінального покарання залежить від його здатності досягати цілей спеціального і загального запобігання. Кримінальне право це не панацея від соціальних та економічних хвороб суспільства.

Е.А. Саркисова стверджує, що основна маса людей не цікавляться, які покарання встановлені законом за ті чи інші злочини, і вони не скоюють злочинів не через страх перед покаранням, а в силу своїх моральних переконань. Погроза законом звернена лише до тих, хто має намір вчинити злочин у силу своїх аморальних якостей, тоді як для більшості людей величина погрози байдужа, оскільки вони дотримуються правових норм добровільно, тому законослухняних громадян немає необхідності попереджати погрозою застосування покарання [9, с. 43-45].

Рівень злочинності залежить від багатьох чинників. Оздоровлення економічної, соціальної, політичної і духовної сфер життя суспільства вимагає грошей і людських ресурсів. Тому іноді держава намагається стримати зростання злочинності суворими санкціями. На перший погляд це здається більш швидким і дешевим способом. Однак практично, за умов незмінного рівня засудження, жорстокість покарання не приводить до позитивного ефекту. Т.А. Денисова наголошує, що як би сьогодні не хотілося швидше скоротити кількість злочинів елементами погроз, посиленням покарання досягти цього неможливо [10, с. 104]. Запобігання злочинам має бути засноване не на страху, а на усуненні причин, що сприяють їх вчиненню.

Якщо особа, котра відбула покарання, не вчиняє нових злочинів лише через страх перед покаранням, яке вона вже випробувала, то 
покарання досягло мети спеціального запобігання, але не досягло мети виправлення. Одночасне досягнення цих двох цілей можливе тоді, коли злочинець у результаті впливу покарання усвідомлює докірність своєї попередньої поведінки.

Поки покарання сприймається злочинцем як образа, він не може оцінити свою поведінку як неправильну, а покарання - як справедливе. Зазначимо, що справедливе покарання має і максимальне загальнозапобіжне значення. Якщо суспільство упевнене в справедливості міри, призначеної винному, то це впливає на свідомість громадян набагато більш ефективно, ніж суворе, але недостатньо обгрунтоване застосування санкцій. Необгрунтовано м'яке чи суворе покарання виключає досягнення цілей, що стоять перед ним, оскільки й у тому і в іншому випадках воно є не тільки незаконним у правовому сенсі, але й несправедливим у загальносоціальному і моральному аспектах [11, с. 159].

Тимчасово досягти мети спеціальної превенції можна за допомогою призначення покарання у виді позбавлення волі. Держава на час виконання покарання намагається захистити суспільство від злочинних посягань. На перший погляд це $є$ ефективним заходом у боротьбі зі злочинністю. Однак ця ефективність має тимчасовий характер, а кінцева мета не завжди досягається, оскільки сутність спеціальної превенції в досягненні постійно тривалого результату. Добре, коли за час виконання покарання засуджена особа виправляється, погано, коли ця мета не досягається йособа продовжує вчиняти злочини. Але набагато гіршим $€$, коли відбування покарання робить людину більш небезпечною для суспільства, ніж до засудження, тобто досягається антимета. Необхідно чітко розуміти, що, вигравши битву, (тимчасово ізолювавши злочинця) держава може програти війну, особа, «зіпсована» покаранням, після звільнення буде довгостроково вчиняти все нові і нові, ще й більш жорстокі, злочини.

Досвід покарання сильно зменшує страх. Особи, котрі відбули тривалі строки позбавлення волі, як правило, не бояться покарання, вони певною мірою звикають до умов життя в місцях позбавлення волі. Крім цього, особистість злочинця найчастіше змінюється в гіршу сторону під тривалим негативним впливом злочинної субкультури (товаришів з ув'язнення). Ув'язнений стає більш ворожим суспільству, його цінностям і менш пристосованим до життя на волі. Ці негативні зміни в особистості важко переборні, тому рецидив різко збільшується в міру збільшення кількості судимостей.

Висновки. Неминучість відповідальності має більше значення для запобігання злочинам, ніж суворість каральних заходів. Іноді держава намагається стримати зростання злочинності суворими санкціями, проте жорстокість покарання не призводить до позитивного ефекту. Жорстокості було більше ніж досить, але злочинності вона не викорінила. Запобігання злочинам будь-якою ціною не може бути принципом кримінальної політики нашої держави. 
Тимчасово досягти мети спеціальної превенції можна за допомогою призначення покарання у виді позбавлення волі, проте кінцева мета не завжди досягається, оскільки сутність запобіжного впливу в досягненні постійно тривалого результату. Недопустимо, щоб відбування покарання робило людину більш небезпечною для суспільства, ніж до засудження (досягається антимета). Покарання у виді позбавлення волі скоріше множить наявні недоліки, ніж усуває їх, висуває нові проблеми, ніж вирішує наявні. На нашу думку, це покарання малоефективне для досягнення мети спеціальної превенції.

Чинне кримінальне законодавство орієнтує суддів на застосування альтернативних позбавленню волі видів покарання. Останніми роками спостерігається тенденція до зменшення питомої ваги позбавлення волі в практиці призначення покарання. Свобода особи в демократичному суспільстві - одна 3 найважливіших соціальних цінностей. I це необхідно враховувати під час організації кримінально-правової протидії злочинності, зокрема під час установлення санкцій у вигляді позбавлення волі.

Застосування альтернативних позбавленню волі видів покарання, на нашу думку, ефективніше, наприклад, звільнення від відбування покарання у виді позбавлення волі з випробуванням. Проте через труднощі на стадії виконання питома вага альтернативних покарань на практиці залишається низькою.

\section{Література}

1. Быков О.А. Главные основания, обуславливающие раз мер уголовного наказания. Тифлис: Издание Кавказского юридического общества, 1894. 77 с.

2. Kalmhout A.M., Tak P.J.P. Sanctionis-Sistem inthe member-states oftheCouncilofEurope. Part I. 1988

3. Филимонов В.Д. Норма уголовного права. Санкт-Петербург: Изд-во «Юрид. центр Пресс», 2004. 281 c.

4. Нисихара Харуо. Обоснование права государства на осуществления уголовного наказания. Вестн. МГУ. Сер. 11. Право. 1991. № 2. С. 72-75.

5. Кристи Н. Пределы наказания / перевод с англ. В.М. Когана. Москва: Изд-во «Прогресс», 1985. 176 с

6. Козлов А.П. Система санкций в уголовном праве. Красноярск: Изд-во Краснояр. ун-та, 1991. 120 c.

7. Даньшин И.Н. За преступление - наказание. Харьков: «Вища школа», 1975. 106 с.

8. Беккариа Ч. О преступлениях и наказаних. Москва: Стелс, 1995. 304 с.

9. Саркисова Э.А. Роль наказания в предупреждении преступлений. Мн.: Навука і тэхніка, 1990. $160 \mathrm{c}$

10. Денисова Т.А. Кримінальне покарання: жорстокість чи необхідність? Держава та регіони. Серія: Право. 2001. № 1. С. 102-105.

11. Козаченко И.Я. Проблемы «зачетного» наказания. Правоведение. 2001. № 1. C. $158-166$. 


\section{А нот а ці я}

Філей Ю. В. Співвідношення гуманізму та ефективності заходів кримінальноправового реагування. - Стаття.

Статтю присвячено співвідношенню гуманізму та ефективності заходів кримінально-правового реагування. У роботі зазначається, що мета закону не в тому, щоб покарати заради кари, а в тому, щоб за допомогою застосування заходів кримінально-правового реагування припинити злочинну діяльність і запобігти вчиненню нових злочинів. Запобігання злочинам будь-якою ціною не може бути принципом кримінальної політики нашої держави.

Ключові слова: гуманізм, злочин, покарання, позбавлення волі,запобігання, протидія.

\section{Ан н от а ци я}

Филей Ю. В. Соотношение гуманизма и эффективности мер уголовно-правового реагирования.- Статья.

Статья посвящена соотношению гуманизма и эффективности мер уголовно-правового реагирования. В работе отмечается, что цель закона не в том, чтобы наказать ради наказания, а в том, чтобы с помощью применения мер уголовно-правового реагирования прекратить преступную деятельность и предотвратить совершение новых преступлений. Предотвращение преступлений любой ценой не может быть принципом уголовной политики нашего государства.

Ключевые слова: гуманизм, преступление, наказание, лишение свободы, предотвращение, противодействие.

\section{S u m m a r y}

Filei $Y u$. V. Ratio between humanism and efficiency of criminal-legal reaction measures. - Article.

The article is devoted to the ratio of humanism and the effectiveness of criminal legal responses. The paper notes that the purpose of the law is not to punish for the sake of punishment, but to stop criminal activity through the use of criminal response measures and prevent the commission of new crimes. Preventing crimes at any cost cannot be the principle of the criminal policy of our state.

Key words: humanism, crime, punishment, imprisonment, prevention, opposition. 